\title{
Tall grass prairie ecosystem management-a gastropod perspective
}

\author{
Annegret Nicolai ${ }^{1,2, *}$, Robert G. Forsyth ${ }^{3}$, Melissa Grantham ${ }^{4}$, and Cary D. Hamel ${ }^{4}$ \\ ${ }^{1}$ Université Rennes, UMR CNRS 6553 EcoBio, Station Biologique Paimpont, Paimpont 35380 France \\ ${ }^{2}$ Western University, Department of Biology, 1151 Richmond Street North, London, Ontario N6A 5B7 Canada \\ ${ }^{3}$ New Brunswick Museum, 277 Douglas Avenue, Saint John, New Brunswick E2K 1E5 Canada \\ ${ }^{4}$ Nature Conservancy of Canada, Manitoba Region, Suite 200 - 611 Corydon Avenue, Winnipeg, Manitoba R3L 0P3 Canada \\ *Corresponding author: annegret.nicolai@univ-rennes1.fr
}

Nicolai, A., R.G. Forsyth, M. Grantham, and C.D. Hamel. 2019. Tall grass prairie ecosystem management-a gastropod perspective. Canadian Field-Naturalist 133(4): 313-324. https://doi.org/10.22621/cfn.v133i4.2217

\begin{abstract}
Less than $5 \%$ of the original tall grass prairie in North America remains. A portion of this remnant, composed of wetland, grassland and forest, is protected by the Nature Conservancy of Canada (NCC) in southern Manitoba. This heterogeneous ecosystem has rich biodiversity; however, gastropods have not been surveyed in Canada's tall grass prairie. We studied gastropods in Prairie, Wet Meadow, Forest, and Wet Forest habitats of the Manitoba Tall Grass Prairie Preserve that vary with respect to land management practices (prescribed burning, grazing by cattle). Gastropod community composition was unique in the Prairie where mounds of grass litter form permanently moist cavities harbouring aquatic species, while dry-habitat species colonized the upper parts of these mounds. Gastropod communities in Prairie habitats were negatively affected by grazing and burning that occurred in the five years prior to our survey. Unburned Forest patches included both forest gastropod species and edge effect influenced open-habitat species and harboured the most diverse gastropod communities. These unburned Forest patches potentially provide a species pool for post-burn prairie recolonization. The gastropod community of Wet Meadows was not affected by grazing and was composed mainly of aquatic species. In this gastropod survey five species were recorded from Manitoba for the first time. The rare Blade Vertigo (Vertigo milium) is also reported.
\end{abstract}

Key words: Fire; grazing; freshwater snails; terrestrial snails and slugs; protected area; rare species; Manitoba

\section{Introduction}

Tall grass prairie once covered 68 million ha of North America before conversion to urban areas or cropland in the United States and Canada-less than 5\% remains (Sampson and Knopf 1994). Tall grass prairie harbours a diversity of terrestrial and aquatic plants and animals within a mosaic of grassland, pothole-forming wetland/grassland systems, and shrubby/ wooded areas. Ecosystem services that include nutrient cycling, water retention, aquifer recharge, the storage of atmospheric carbon, as well as enhanced water infiltration and improved runoff water quality are all of great ecological and economic importance (Glaser 2012). As a result of human activity, prairies are the most highly impacted of any of the continent's terrestrial ecosystems. Current threats to the biodiversity and ecological functioning of the remaining tall grass prairie include: habitat fragmentation, loss by conversion to cropland, incompatible grazing practices, undesirable habitat changes due to fire and fire exclusion, spread of invasive plant species, and stream degradation due to incompatible land management practices and soil erosion (Glaser 2012).
The biodiversity of northern tall grass prairie has been poorly explored, especially that of soil related functional animal groups, such as terrestrial gastropods. Terrestrial gastropods are generally under-surveyed in most of Canada and are usually absent from management strategies for protected areas. Being a significant component of biodiversity among ground dwelling species, terrestrial gastropods are globally declining (Lydeard et al. 2004) and play a crucial role in ecological processes (Jordan and Black 2012) by aiding in decomposition, nutrient cycling and soil building processes, and by providing food and essential nutrients to wildlife. Also, terrestrial gastropod abundance and diversity can be used as ecological indicators at the litter-soil interface, such as for logging practice management in forests (British Columbia Ministry of Forests 2008). Previously, only a few terrestrial gastropod surveys have occurred in Manitoba, e.g., by the Manitoba Museum and by Nekola (2005), and none of these targetted the community in the tall grass prairie.

Humans have long used fire to influence North American ecosystems, including First Nations who

$\overline{\text { A contribution }}$ towards the cost of this publication has been provided by the Thomas Manning Memorial Fund of the Ottawa Field-Naturalists' Club. 
used fire to create large areas of grassland in the Great Plains regions (Pyne 1983; Botkin 1990). While First Nations used fire to promote a habitat mosaic and a resource diversity that provided greater stability to their lives, later European settlers used burns to create uniformity in ecosystems (Lewis 1985). Prescribed fire has become an important management tool for prairie and forest conservation in North America (Gottesfeld 1994; Williams 2000), and is used to limit the spread of invasive plants (Brooks and Lusk 2008), promote growth and reproduction in native prairie vegetation (Towne and Owensby 1984), and improve and expand habitat for grassland and parkland birds (e.g., Burkman 1993; Madden et al. 1999; Davis et al. 2000; Ludwick and Murphy 2006; Vierling and Lentile 2006; Buehler et al. 2007; Grant et al. 2010; Klaus et al. 2010; Austin and Buhl 2013) and rare prairie plants (e.g., Becker 1989; Bleho et al. 2015). Some authors have expressed concern about the detrimental impacts of prescribed burns on prairie that include providing optimal germinating conditions for invasive plant seedlings by opening the vegetation canopy (Ohrtman et al. 2011), and negative direct and indirect effects on the abundance of small mammals (Kaufman et al. 1990), birds (Reinking 2005), arthropods (Swengel 1996; Harper et al. 2000), and terrestrial gastropods (Nekola 2002; reviewed by Saestedt and Ramundo 1990; Knapp et al. 2009).

In addition to structural modification by fire, tall grass prairie has also been intermittently grazed by large ungulates, i.e., Bison (Bison bison; Knapp et al. 1999). Domestic Cattle (Bos taurus) are now the dominant grazers at most prairie sites. Grazing can enhance plant diversity by encouraging the growth of some prairie species (Damhoureyeh and Hartnett 1997, 2002). The effect on prairie fauna is also selective; birds (Sliwinski 2012 as cited in Glaser 2012), arthropods (van Klink et al. 2015), and terrestrial gastropods (Baur et al. 2007) respond differently to grazing regimes, defined by stocking rate, grazing frequency, and livestock type.

One of the largest remaining tall grass prairie complexes in Manitoba is protected by the Nature Conservancy of Canada (NCC) and partners as part of the Manitoba Tall Grass Prairie Preserve (MTGPP). As part of an effort to preserve tall grass prairie biodiversity and the ecosystem services it provides, managers need to understand how management practices influence the gastropod community in the MTGPP. Currently, the NCC uses rotational prescribed burning and grazing by cattle to maintain a spatial and structural mosaic of grassland, wetland, and forest within the tall grass prairie system. For managers of protected prairie habitat, such as the NCC, the question of which management strategy to apply remains an ongoing challenge. The goal is to identify the appropriate regime of prescribed burns and grazing required to maintain a generally rich floral and faunal diversity without negatively affecting the diversity of functional groups, such as gastropods involved in litter-soil processes, or those of conservation concern. To assess the impact of current management practices on the composition of the gastropod community in the MTGPP a gastropod survey was undertaken at variously managed sites (burning or grazing within the past five years) within the preserve.

\section{Study Area}

The 4100 ha MTGPP is located in the rural municipality of Stuartburn, in southeastern Manitoba, Canada (Figure 1). The majority ( $>70 \%$ ) of MTGPP lands are owned by the NCC; the Manitoba Habitat Heritage Corporation and Nature Manitoba own the remainder. Preserve lands are jointly managed through a Management Committee that includes landowners as well as Manitoba Sustainable Development and Environment and Climate Change Canada. The preserve is comprised of dozens of distinct management units, allowing temporal and spatial variation in management practices.

The habitats comprise two grassland types (Prairie and Wet Meadow) and two woodland patches (Forest and Wet Forest). The two woodland types range from small groves to larger forest areas and provide mostly edge habitat, but also include humid microhabitats under logs and drier microhabitats on the surface of logs and on branches. The habitat types (classification based on Minnesota Department of Natural Resources 2005) differ in vegetation composition and structure as well as in seasonal cycle of flooding as follows:

\section{Prairie (P)}

Tall grass prairie communities dominated by tall and mid-height graminoid species up to $1.50 \mathrm{~m}$ tall. Big Bluestem (Andropogon gerardi Vitman), Prairie Dropseed (Sporobolus heterolepis (A. Gray) A. Gray), Little Bluestem (Schizachyrium scoparium (Michaux) Nash), Yellow Indiangrass (Sorghastrum nutans (L.) Nash), and Plains Porcupine Grass (Hesperostipa spartea (Trinius) Barkworth) are most common. Not flooded but forming very humid microhabitats of roots and decaying grass leaves in the upper soil layer between mounds of grass.

\section{Wet Meadow (WM)}

Meadow dominated by graminoid species up to $0.50 \mathrm{~m}$ tall. Broad-leaved species such as Slimstemmed Reedgrass (Calamagrostis stricta (Timm) Koeler), Prairie Cordgrass (Sporobolus michauxianus (Hitchcock) P.M. Peterson \& Saarela), Sartwell's Sedge (Carex sartwellii Dewey), and Woolly Sedge 


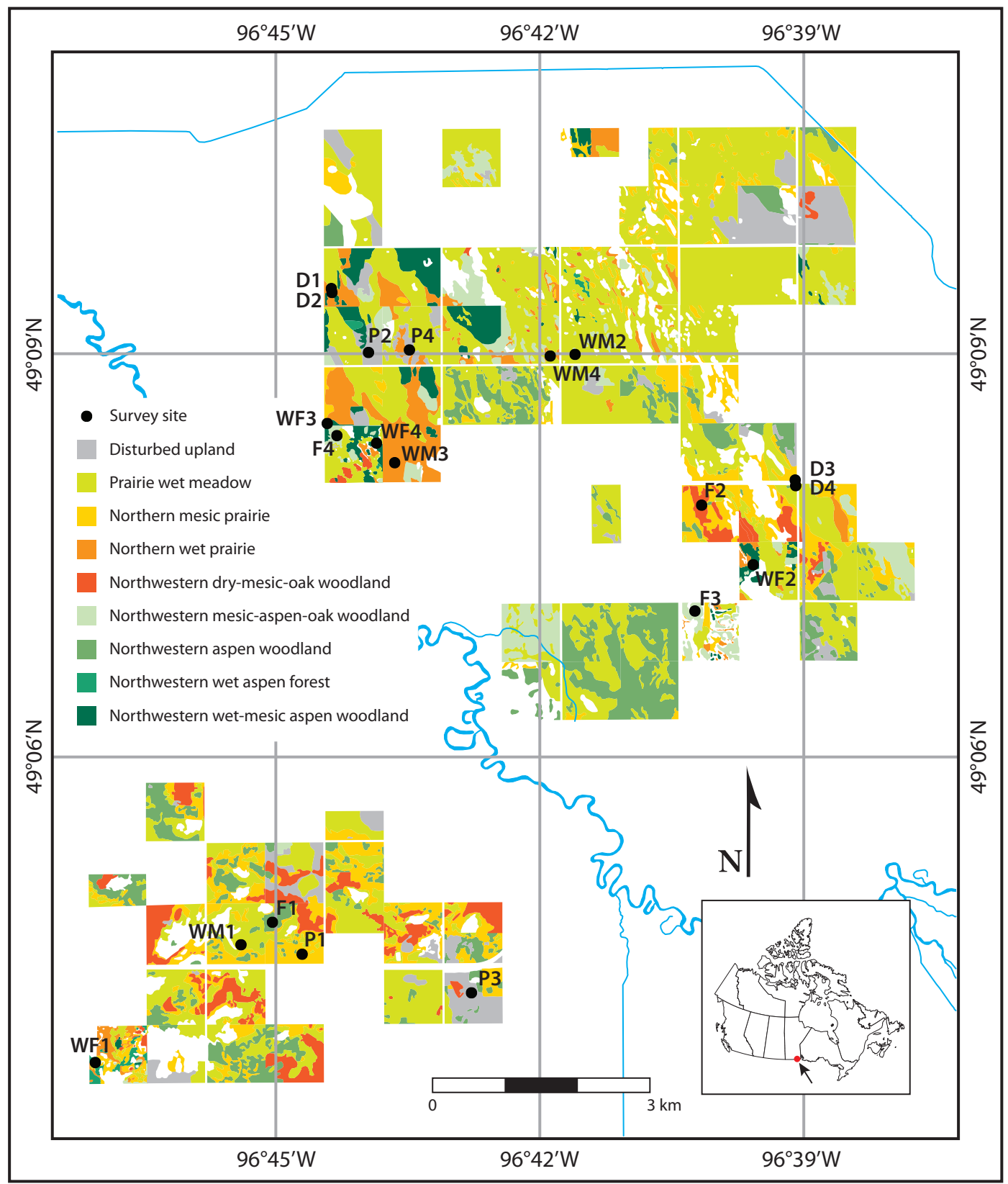

Figure 1. Phytosociology classification in the Manitoba Tall Grass Prairie Preserve and gastropod survey sites: $F=$ Forest, $\mathrm{WF}=$ Wet Forest, $\mathrm{P}=$ Prairie, $\mathrm{WM}=$ Wet Meadow. Two drainage sites have also been analyzed, D1/D2 and D3/D4, with sampling points on each side of the road.

(Carex pellita Muhlenberg ex Willdenow) are typical, with Tussock Sedge (Carex stricta Lamarck) an occasional dominant. Habitat is subjected to moderate inundation by standing water following spring thaw and heavy rains, and to periodic drawdowns during the summer.

\section{Forest (F)}

Forest patches within the grassland that are not flooded and are dominated by trees and herbaceous species. Herbaceous plant cover commonly includes: Wild Lily-of-the-valley (Maianthemum canadense Desfontaines), Northern Bedstraw (Galium boreale 
L.), Wild Sarsaparilla (Aralia nudicaulis L.), American Vetch (Vicia americana Muhlenberg ex Willdenow), and Lindley's Aster (Symphyotrichum ciliolatum (Lindley) Á. Löve \& D. Löve). Bur Oak (Quercus macrocarpa Michaux) and Trembling Aspen (Populus tremuloides Michaux) are dominant tree species.

\section{Wet Forest (WF)}

Forest patches dominated by trees and herbaceous species that are subjected to the same inundation regime as Wet Meadow sites. Herbaceous cover commonly includes: Star-flowered False Solomon's Seal (Maianthemum stellatum (L.) Link), Wild Strawberry (Fragaria virginiana Miller), Northern Bedstraw ( $G$. boreale), Calico Aster (Symphyotrichum lateriflorum (L.) Á. Löve \& D. Löve), and Dwarf Raspberry (Rubus pubescens Rafinesque). Trembling Aspen (Populus tremuloides), Balsam Poplar (Populus balsamifera L.), or Black Ash (Fraxinus nigra Marshall) are the most important tree species.

Historical and recent fire and grazing management on MTGPP property is highly diverse; there is no specific information on the historical frequency of grazing or burning for this area. Long-term management plans include prescribed burns once every five years, typically in spring or fall. In the year prior to prescribed fire, properties are not grazed. However, the interval between fires can be variable due to occasional wildfires and seasonal weather conditions not conducive to the use of prescribed fire (Bleho et al. 2015). A twice-over rotational grazing system is used at the MTGPP but is individually managed by cattle owners. Information on frequency and intensity of grazing and fire was not available. Timing of fire and grazing (Table 1) was based on best available information.

Sites within historically human-built drains are also part of the MTGPP ecosystem, and potentially could serve as a source for post-management recolonization by gastropods. Drainage wells were therefore also investigated for richness and abundance of aquatic gastropods that might be available to colonize wet and flooded grassland or forest habitat.

\section{Methods}

All sites $(n=16)$ examined within the MTGPP had been managed either by burning or grazing (exclusively cattle) within the last five years $(n=10)$ or had received no active management over the past five years or more $(n=6)$. Although we were able to sample recently managed $(<5$ years) and unmanaged $(\geq 5$ years) sites for both woodland and grassland habitat types, we were unable to find any Wet Forest that had been subject to both grazing and burning in the previous five years (Table 1).
In September 2013, a visual search and hand collection of gastropods occurred in the litter and the uppermost soil layer using six $0.2 \times 0.2 \mathrm{~m}$ plots per site (Figure 1). The plots were separated by a distance of at least $20 \mathrm{~m}$ on a random, non-linear transect to sample different microhabitats within the same vegetation zone (= site). Additionally, four drainage-well sites of $10 \times 10 \mathrm{~m}$ were searched during $30 \mathrm{~min}$ each for aquatic gastropod species to establish the full gastropod species list in the MTGPP.

Gastropods were identified by A.N. and R.G.F. Vouchers of all species have been deposited in the Manitoba Museum (Catalogue numbers: MM65991 to MM65999 and MM66178 to MM66311). Live gastropods were stored as wet samples at the Biodiversity Institute of Ontario (BIO), Guelph, Ontario, and incorporated into the BOLD database under field sample numbers ANi039 to ANi056 and under the BIO collection numbers BIOUG09921-C08 to -C09 and BIOUG09922-B10, -C02, -C05 to -C07, -C10 to -C12, -D01 to -D07, -E01, -E03 to -E12, and -F02. Individuals of each species were counted to determine abundance $/ \mathrm{m}^{2}$ for each site.

Due to the diversity of management combinations, it was not possible to assemble a set of replicates, so we used an exploratory approach in our multivariate analysis. Species richness was compared among habitat types using an adjusted $t$-test (Welch) and one-way analysis of variance (ANOVA). The gastropod community composition was analysed with nonmetric multidimensional scaling (NMDS) with Euclidean distance similarity coefficient applied to

TABLE 1. Management history of the sites in the Tall Grass Prairie Preserve, Manitoba, prior to the 2013 sampling year. Information about grazing was available since 1993 and about fire since 1992. $\mathrm{F}=$ Forest, WF $=$ Wet Forest, $\mathrm{P}=$ Prairie, $\mathrm{WM}=$ Wet Meadow.

\begin{tabular}{clcc}
\hline \hline Habitat & Sites & $\begin{array}{c}\text { Years since } \\
\text { last grazing }\end{array}$ & $\begin{array}{c}\text { Years since } \\
\text { last fire }\end{array}$ \\
\hline Woodland & F1 & 5 & 2 \\
& F2 & 1 & 10 \\
& F3 & $<20$ & $<21$ \\
& F4 & $<20$ & $<21$ \\
& WF1 & $<20$ & 2 \\
& WF2 & 1 & $<21$ \\
& WF3 & $<20$ & $<21$ \\
& WF4 & $<20$ & $<21$ \\
& P1 & 5 & 2 \\
& P2 & 2 & $<21$ \\
& P3 & 5 & $<21$ \\
& P4 & $<20$ & $<21$ \\
& WM1 & 5 & 2 \\
& WM2 & 1 & $<21$ \\
& WM3 & $<20$ & $<21$ \\
& WM4 & $<20$ & 7 \\
\hline \hline
\end{tabular}


abundance data $\left(\mathrm{N} / \mathrm{m}^{2}\right)$ based on the normalized minimal threshold density (Legendre and Legendre 2007; Ramette 2007). The stress coefficient indicates the badness-of-fit, this is the quality of the NMDS (S < 0.10: good). Mann-Whitney and KruskalWallis tests were used on scores of the axes to analyse gastropod community differences between habitat types. Hierarchical clustering was performed with the centroid method on a Euclidean distance matrix calculated on the abundance of gastropods $\left(\mathrm{N} / \mathrm{m}^{2}\right)$. Approximately unbiased $P$-values were computed by multiscale bootstrap resampling, $n=1000$ (Shimodaira 2004). Spatial autocorrelation of community composition was analysed with the Mantel test using Euclidean distance and $n=1000$ permutations. Moran's I was calculated for species richness on an inverse distance matrix. All analyses were conducted with the software R 2.8.0 (R Core Team 2008).

\section{Results}

The forest and grassland communities formed by terrestrial and aquatic species are distinguishable on the NMDS model (Figure 2) by scores on the first axis (Mann-Whitney, $W=55, n=16, P=0.01$ ) and on the third axis (Mann-Whitney, $W=53, n=16, P=0.03$ ), but not on the second axis (Mann-Whitney, $W=41$, $n=16, P=0.38$ ). Species richness (Table 2) did not differ between forest and grassland communities ( $t$ test, $t_{11.93}=0.88, P=0.39$ ). Likewise, species composition (measured as scores on the three NMDS axes; Figure 2) and species richness (Table 2) were not significantly different among Forest, Wet Forest (forest communities), Prairie and Wet Meadow (grassland communities; axis 1: Kruskal-Wallis, $\chi_{3}^{2}=6.9, P=$ 0.07 ; axis 2: Kruskal-Wallis, $\chi_{3}^{2}=1.3, P=0.73$; axis 3: Kruskal-Wallis, $\chi_{3}^{2}=5.1, P=0.16$; species richness: ANOVA, $F_{l, 12}=0.27, P=0.84$ ). Nevertheless, nine of 23 gastropod species showed habitat preference based on presence in a single habitat type (Table 2). Among aquatic gastropods, six of nine species are characterized as vernal species (Clarke 1981), being generally restricted to periodically flooded terrestrial habitats (Table 2). Only two of the vernal species were absent from the drainage well sites (with permanent water). Some typically open-habitat species, such as Costate Vallonia (Vallonia costata (O.F. Müller, 1774)) and Trumpet Vallonia (Vallonia parvula Sterki, 1893), were only observed at the forest edge. Glossy Pillar (Cochlicopa lubrica (O.F. Müller, 1774)), Small Spot (Punctum minutissimum (I. Lea, 1841)), and V. parvula were only found in the dry, unflooded, Forest, while Tapered Vertigo (Vertigo elatior Sterki, 1894), a species preferring very wet habitats (Nekola and Coles 2010), only occurred in the Wet Forest. Blade Vertigo (Vertigo milium (Gould, 1840)), a wet grassland species (Nekola and Coles 2010), was only recorded in Prairie sites while Multirib Vallonia (Vallonia gracilicosta Reinhardt, 1883) occurred only in Wet Meadow. Marsh Hive (Euconulus cf. praticola (Reinhardt, 1883); = E. alderi (Gray, 1840), see Forsyth and Oldham 2016), also a wet grassland species (Forsyth 2004, 2005), occurred in both grassland habitats.

The cluster analysis of the gastropod community composition (Figure 3) based on the distances in the NMDS model (Figure 2) showed three distinctive clusters (cluster P3-P4, cluster WM2-WM4, and a cluster including the remaining sites) that were not explained by spatial autocorrelation (Mantel test, $z=-0.03, P=0.50)$. Moreover, species richness was not spatially autocorrelated (Moran test, $I_{o b s}=-0.16$, $I_{\text {exp }}=-0.07, \mathrm{SD}=0.11, P=0.38$ ). This result indicated that management practices may influence gastropod community composition in some habitats. While, two recently managed Prairie sites, P1 and P2, were not significantly different from most sites (Figures 3 and 4a), P3 and P4, left unmanaged for at least five years, had a unique community composition characterized by high abundance of aquatic species (Figures 3 and 4a). P3 and P4 had deep litter filled holes between mounds of grass, whereas recently burned

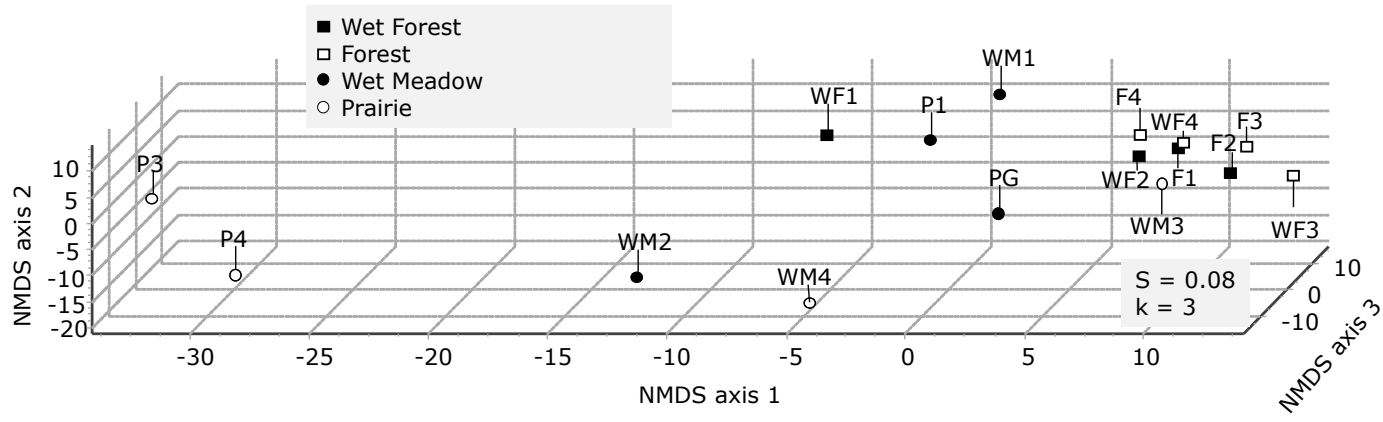

FIGURE 2. NMDS plot of gastropod communities in different habitats occurring in the Tall Grass Prairie. S indicates the stress and $\mathrm{k}$ the total number of axes used in the analysis. $\mathrm{F}=$ Forest, $\mathrm{WF}=$ Wet Forest, $\mathrm{P}=$ Prairie, $\mathrm{WM}=\mathrm{Wet} \mathrm{Meadow}$. 
TABLE 2. Frequency and abundance of gastropods in different habitats in the Tall Grass Prairie Preserve, Manitoba (frequency / minimal-maximal abundance per $\mathrm{m}^{2}$ in four sites per habitat). Species richness is indicated as mean $\pm \mathrm{SE}$.

\begin{tabular}{|c|c|c|c|c|c|c|}
\hline \multirow[b]{2}{*}{ Family } & \multirow[b]{2}{*}{ Species } & \multicolumn{2}{|c|}{ Woodland } & \multicolumn{2}{|c|}{ Grassland } & \multirow[b]{2}{*}{ Drainage } \\
\hline & & Forest & Wet Forest & Prairie & $\begin{array}{c}\text { Wet } \\
\text { Meadow }\end{array}$ & \\
\hline \multicolumn{7}{|c|}{ Terrestrial gastropods } \\
\hline Agriolimacidae & Deroceras laeve, Meadow Slug & $4 / 3-5$ & $4 / 3-5$ & $1 / 3$ & & \\
\hline Cochlicopidae & Cochlicopa lubrica, Glossy Pillar & $1 / 3$ & & & & \\
\hline Discidae & Discus whitneyi, Forest Disc & $3 / 3-5$ & $2 / 3-8$ & & & \\
\hline \multirow{3}{*}{ Euconulidae } & Euconulus fulvus, Brown Hive & & $1 / 8$ & & & \\
\hline & Euconulus polygyratus, Fat Hive & $2 / 3-8$ & $3 / 5-11$ & $2 / 3-24$ & $3 / 5-21$ & $2 / 2-3$ \\
\hline & Euconulus cf. praticola, Marsh Hive & & & $1 / 3$ & $1 / 24$ & \\
\hline \multirow[t]{3}{*}{ Gastrodontidae } & Nesovitrea electrina, Amber Glass & $3 / 8-16$ & $4 / 3-16$ & $3 / 13-37$ & $4 / 8-32$ & \\
\hline & Striatura milium, Fine-ribbed Striate & & $1 / 3$ & & & \\
\hline & Zonitoides arboreus, Quick Gloss & $4 / 5-19$ & $2 / 21-27$ & $1 / 3$ & $3 / 3-5$ & \\
\hline Punctidae & Punctum minutissimum, Small Spot & $1 / 3$ & & & & \\
\hline Pristilomatidae & Hawaiia minuscula, Minute Gem & & & $2 / 5-11$ & $1 / 13$ & \\
\hline \multirow[t]{3}{*}{ Succineidae } & $\begin{array}{l}\text { Mediappendix cf. vermeta, Suboval } \\
\text { Ambersnail }\end{array}$ & $1 / 3$ & $2 / 3-5$ & $2 / 3-11$ & $2 / 5-16$ & $1 / 3$ \\
\hline & Novisuccinea ovalis, Oval Ambersnail & $2 / 5-11$ & $2 / 3-16$ & & $1 / 11$ & \\
\hline & Oxyloma sp., an ambersnail & & $1 / 13$ & $1 / 16$ & & $3 / 3-5$ \\
\hline \multirow[t]{4}{*}{ Valloniidae } & Vallonia costata, Costate Vallonia & & $1 / 3$ & & & \\
\hline & Vallonia gracilicosta, Multirib Vallonia & & & & $1 / 3$ & \\
\hline & Vallonia parvula, Trumpet Vallonia & $1 / 3$ & & & & \\
\hline & Vallonia pulchella, Lovely Vallonia & $1 / 3$ & & $2 / 3-8$ & $1 / 27$ & \\
\hline \multirow[t]{4}{*}{ Vertiginidae } & $\begin{array}{l}\text { Gastrocopta tappaniana, White } \\
\text { Snaggletooth }\end{array}$ & & & $1 / 5$ & $1 / 8$ & \\
\hline & Vertigo elatior, Tapered Vertigo & & $1 / 3$ & & & \\
\hline & Vertigo milium, Blade Vertigo & & & $1 / 3$ & & \\
\hline & Vertigo ovata, Ovate Ambersnail & & & $1 / 3$ & $1 / 8$ & \\
\hline Vitrinidae & Vitrina angelicae, Eastern Glass-snail & $2 / 5-6$ & $1 / 3$ & & & \\
\hline \multicolumn{7}{|c|}{ Aquatic gastropods } \\
\hline Lymnaeidae & Galba sp., a fossaria & & & $4 / 13-104$ & $3 / 5-53$ & $2 / 8-9$ \\
\hline & Stagnicola elodes, Marsh Pondsnail & $1 / 8$ & $1 / 16$ & & $3 / 3-11$ & $4 / 3-24$ \\
\hline \multirow[t]{5}{*}{ Planorbidae } & Gyraulus circumstriatus, Disc Gyro & & & & & $1 / 24$ \\
\hline & Gyraulus parvus, Ash Gyro & & & $3 / 3-32$ & $2 / 8-13$ & \\
\hline & $\begin{array}{l}\text { Planorbella subcrenata, Rough } \\
\text { Ramshorn }\end{array}$ & & & & $1 / 8$ & \\
\hline & Planorbella trivolvis, Marsh Ramshorn & & & & & $1 / 5$ \\
\hline & $\begin{array}{l}\text { Promenetus umbilicatellus, Umbilicate } \\
\text { Sprite }\end{array}$ & $1 / 8$ & $1 / 3$ & 3/8-19 & $2 / 48-59$ & $4 / 8-27$ \\
\hline \multirow[t]{2}{*}{ Physidae } & Aplexa elongata, Lance Aplexa & $1 / 3$ & $4 / 3-56$ & $3 / 5-48$ & $3 / 5-45$ & $4 / 19-61$ \\
\hline & Physella gyrina, Tadpole Physa & & & & & $2 / 8-21$ \\
\hline Species richness & & $7.0 \pm 1.3$ & $7.3 \pm 1.3$ & $7.8 \pm 1.0$ & $8.3 \pm 0.5$ & $6.0 \pm 1.1$ \\
\hline
\end{tabular}

Prairie (P1, Table 1) had bare soil between small grass mounds over most of the habitat. A recently grazed Prairie (P2, Table 1) had smaller grass mounds and less litter than unmanaged Prairie, but the structure of the vegetation and the grass litter were not quantified. Although P1 and P2 had been managed within the past two years prior to our study, their gastropod community composition was similar to those of Forest and Wet Forest. In the Wet Meadow, the recently grazed (WM2) and unmanaged WM4 formed a cluster distinct from the remaining sites (Figures 2 and 3). WM2 and WM4, sites separated only by a small gravel road, had a higher abundance of aquatic species (Figure 5a) relative to other Wet Meadow sites (WM1 and WM3, Figure 5b).

\section{Discussion}

The prairie ecosystem is a patchy assemblage of grassland, groves, and small forests. In general, the different habitats are moist due to periodic flooding, especially in the Wet Forest and Wet Meadow. Species richness and gastropod community composition are driven by climate parameters such as water balance at a large sub-continental scale (Horsák and Chytry 2014) and by soil moisture, temperature, and calcium-content at a local scale (Dvořáková and 


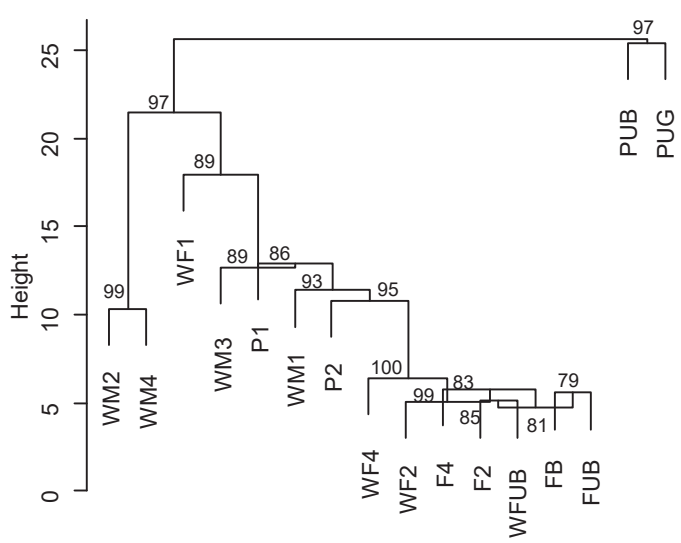

Figure 3. Dendrogram of gastropod community clusters in different habitats occurring in the Tall Grass Prairie. Approximately unbiased $P$-value computed by multiscale bootstrap resampling $(n=1000)$ are indicated on the branches. $\mathrm{F}=$ Forest, $\mathrm{WF}=$ Wet Forest, $\mathrm{P}=$ Prairie, $\mathrm{WM}=$ Wet Meadow.
Horsák 2012; Hettenbergerová et al. 2013). Because of the small size of the forest patches, most of the forested habitat includes forest edges that are suitable for open land species. Therefore, community composition in general is very similar for most grassland and woodland sites. However, the Prairie sites, when undisturbed by human activity, host a very particular gastropod community, characterized by the presence of vernal species, such as Lance Aplexa (Aplexa elongata (Say, 1821)) and Umbilicate Sprite (Promenetus umbilicatellus (Cockerell, 1887)), and the presence of dry-habitat species, such as Lovely Vallonia (Vallonia pulchella (O.F. Müller, 1774)) and V. gracilicosta. Dead vegetation accumulates in prairie habitat over years to form mounds of grass litter. Within these mounds, cavities retain water permanently. This permanent water availability allows aquatic species to colonize the cavities within mounds of grass litter, while upper parts of the mounds are exposed to drying and are suitable for dry-habitat species. Burning

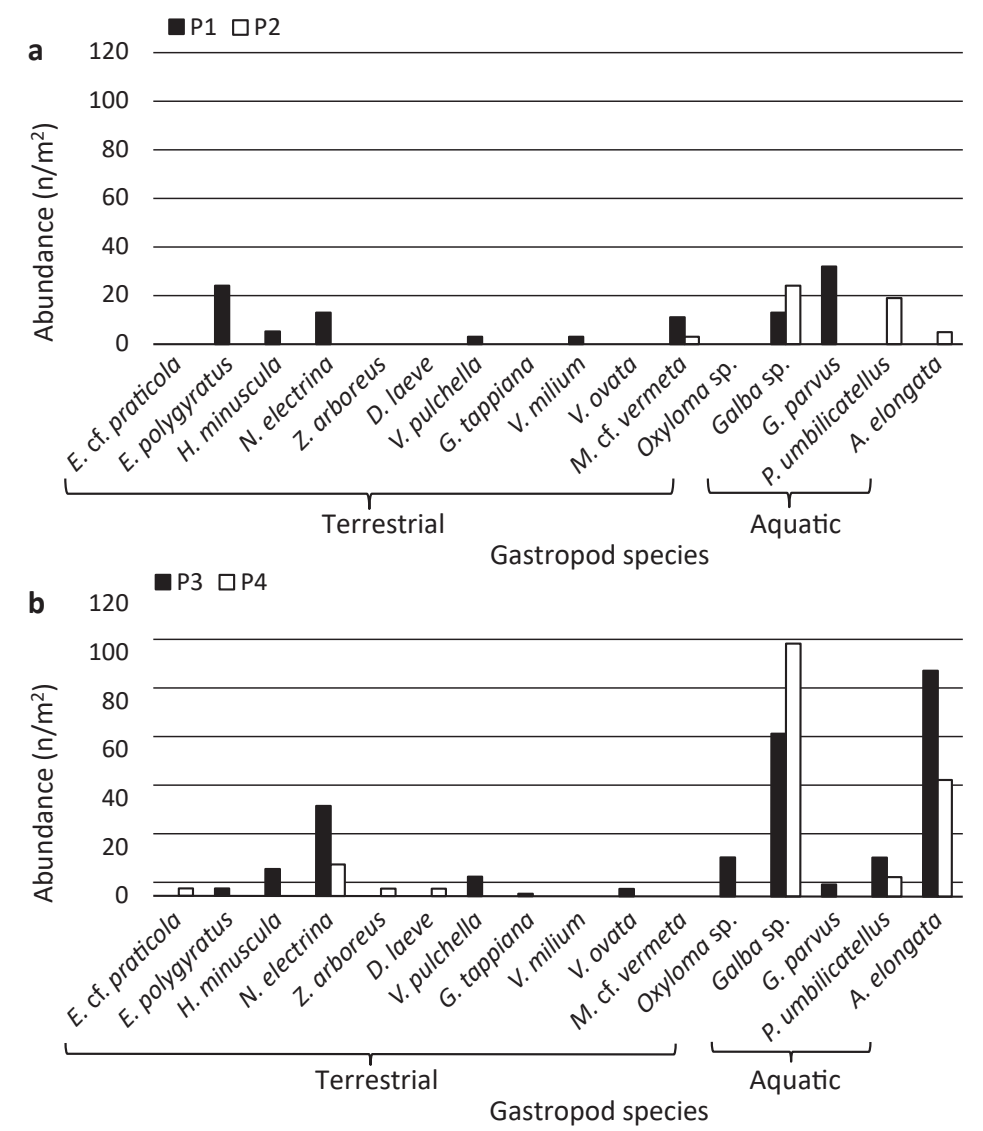

FigUre 4. Abundance of gastropod species in a. recently burned (P1) and grazed (P2) Prairies, and in b. Prairies where the last management was at least five years ago, in the Tall Grass Prairie Preserve in Manitoba. P3 and P4 form a distinct cluster in the NMDS model (see Figures 2 and 3). Pooled species richness for P1 and P2 is six terrestrial and four aquatic gastropod species, and for P3 and P4 is 10 terrestrial and four aquatic gastropod species. See Table 2 for full species names. 


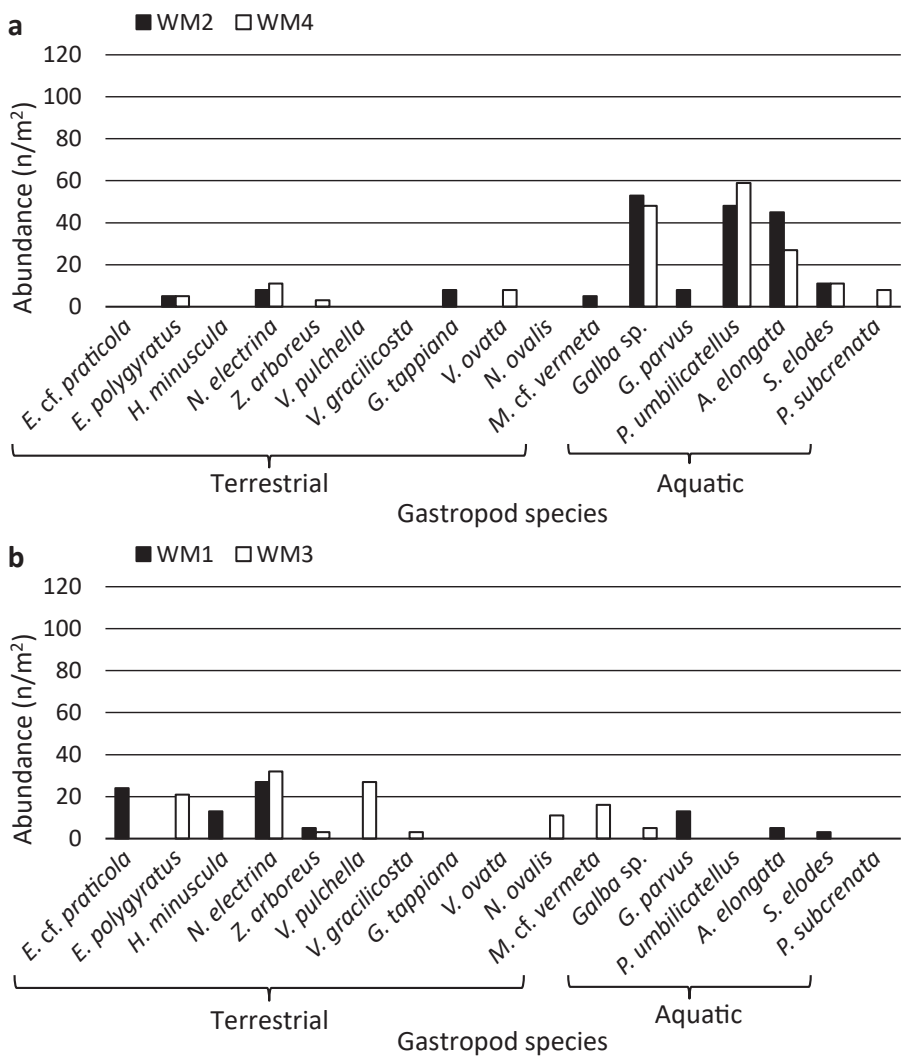

Figure 5. Abundance of gastropod species in a. recently grazed Wet Meadow (WM2) and in a Wet Meadow where the last management was at least five years ago (WM4), and in b. recently burned Wet Meadow (WM1) and in a Wet Meadow where the last management was at least five years ago (WM3), in the Tall Grass Prairie Preserve in Manitoba. WM2 and WM4 form a distinct cluster in the NMDS model (see Figures 2 and 3). Pooled species richness for WM1 and WM3 is nine terrestrial and four aquatic gastropod species, and for WM2 and WM4 is six terrestrial and six aquatic gastropod species. See Table 2 for full species names.

and grazing, as well as trampling by cattle, may reduce the mounds of grass litter and impact the aquatic micro-habitat. For this reason, only undisturbed Prairie sites are unique, harbouring a gastropod community composed of both aquatic and dry habitat species. However, our characterization of sites as "undisturbed" or "unmanaged" only means that they have not be subject to grazing or burning in recent years. All sites sampled had a prior history of burning and grazing, with the rotation of these land management practices over time and space nonetheless responsible for this unique faunal assemblage. Without fire at some point, these sites would all have transitioned to Forest or Wet Forest, and thus harbour a different gastropod community. Short term declines in gastropod diversity or abundance that result from management measures may be an essential part of ensuring the long term maintenance of both grassland and the gastropod species dependent on open habitats.

Nekola (2002) indicates that frequent prescribed burns represent a significant threat to the diversity of grassland snail communities, directly and indirectly affecting snail survival. Snails in the upper litter layer die from exposure to high heat during burning (Nekola 2002). Post-burn mortality of snails is also high due to desiccation, due to the loss of shelter and micro-habitats (Ray and Bergey 2015). Fire destroys that part of the soil habitat upon which most litter-soil organisms depend and is therefore the most important factor affecting survival (Bellido 1987). In prairie habitat this means the loss of mounds of grass litter forming moist cavities. At the recently burned Prairie sites soil was bare between the re-establishing mounds of grass litter, but moist cavities were absent. Therefore, aquatic species were negatively affected by the loss of micro-habitat. Burning may be beneficial for forest/grassland species, such as $V$. milium (only observed in the burned Prairie site in our study), which can exploit open-burned habitat close to the forest edge. Similarly, in the 
Mediterranean region Santos et al. (2012) only found gastropods of the family Geomitridae: Montserrat Heath Snail (Xerocrassa montserratensis (Hidalgo, 1870)) and Striped Heath Snail (Xerocrassa penchinati (Bourguignat, 1868)), two endemic open-habitat species, in burned sites. The availability of cryptic refuges within these Mediterranean forest patches (Kiss and Magnin 2003, 2006) presumably facilitates the survival of open-habitat snail populations (Santos et al. 2012). Likewise, in the tall grass prairie system, the manner in which fire spreads through burn units varies depending on habitat and weather conditions. Skips, or 'refugia', within the burn extent are common (Sveinson Pelc 2013). The resulting patchy consumption of litter layer and exposure of mineral soil allows recolonization from unburned areas. The result is that most sites recently burned ( $<2$ years) had gastropod composition similar to unmanaged sites, demonstrating rapid recolonization in this patchy ecosystem. Ray and Bergey (2015) showed that in favourable weather conditions snail communities in post-burn habitats that include leaf litter showed growth rate increases due to higher soil $\mathrm{pH}$ following fire. In Prairie habitat once reestablishment of the litter layer is underway, recolonization from adjacent sites such as Wet Forest patches or drainage sites (especially by aquatic species) can be rapid.

Grazing also contributes to the preservation of the prairie ecosystem mosaic by limiting the spread of woody species and the expansion of forest. In the Tall Grass Prairie Preserve grazing had a significant effect on snail community composition only at Prairie sites where vegetation structure was destroyed. At other sites, grazing intensity (frequency, number of animals, length of grazing period, and their combinations) may be low enough to keep disturbance below a threshold and to maintain snail species composition. When formerly managed grassland was abandoned in Romania, open-habitat gastropod species decreased (Cremene et al. 2005). However, grazing intensity negatively influenced the snail fauna in Swiss grasslands, independent of livestock species (Boschi and Baur 2007). Different mechanisms involved in grazing may affect the snail community. The choice of food plants by livestock may impact seed dispersal and therefore plant composition, affecting food sources and micro-habitat for snails. Also, trampling may affect snail survival directly, or indirectly by destroying micro-habitat (Fischer et al. 1996; Rook et al. 2004). In the Tall Grass Prairie Preserve the structure of mounds of grass litter in Wet Meadow is less important than in Prairie sites. Aquatic species might take more advantage of long periods of flooding in the former. Also, drainages are usually wet and provide a species pool for colonizing wet meadows af- ter periods of drought. Dry-habitat species were absent from the Wet Meadow, however some terrestrial gastropods, such as Fat Hive (Euconulus polygyratus (Pilsbry, 1899)) and Amber Glass (Nesovitrea electrina (Gould, 1841)) are adapted to both moist and dry habitats and, were present, in Wet Meadow. Two Wet Meadow sites were distinct from all others due to a high abundance of aquatic species which may be the result of a particular flooding regime.

Management recommendations for grasslands in general include low intensity burns that preserve the organic litter layer. Intervals between burns of $>5$ years (Kiss and Magnin 2006) and $>15$ years (Nekola 2002) have been recommended to allow for restoration of the gastropod community. However, it is not clear if an interval $>15$ years would apply in the MTGPP system, where fire rotation historically has ranged 3-6 years (Hamel et al. 2006) and is currently 5-6 years. Unfortunately, the gastropod community composition prior to this management strategy is unknown. First Nation fire management was also frequent $(<5$ years; Lewis 1985). Our observations suggest that short burn intervals have low impact when habitat is patchy, and gastropods can easily recolonize from adjacent unburned areas. In European grasslands, Boschi and Baur (2007) advise extensive grazing. Independent of livestock species, the number of livestock present and the duration of grazing has an impact on the gastropod community. Because there can be an interaction between different management methods (Damhoureyeh and Hartnett 1997), it is difficult to predict the effect of the highly diverse fire-grazing management combinations on gastropod communities in the different habitats of the tall grass prairie system.

Mounds and leaf litter seem to be important for populations of gastropods to recover after burns. Leaf litter supplementation may be a management option.

The gastropod fauna of Manitoba is poorly known and there is little information on the terrestrial molluscs of the Canadian prairie ecosystem. This study increases our knowledge concerning the range of V. parvula, P. minutissimum, Fine-ribbed Striate (Striatura milium (Morse, 1859)), E. cf. praticola, and Suboval Ambersnail (Mediappendix cf. vermeta (Say, 1829)), all recorded for the first time in Manitoba during our study. Vertigo milium, reported previously in Canada only from a few sites in Ontario and one site in Manitoba (Nekola and Coles 2010) is ranked as Nationally Imperilled to Vulnerable (N2N3, CESCC 2016). Galba Schrank, 1803 sp. could not be identified to species because of taxonomic issues, and uncommon grassland species/subspecies within the genus, recorded previously in Alberta (Boag and Wishart 1982) are poorly known. 


\section{Acknowledgements}

We would like to thank the Nature Conservancy of Canada (NCC) for funding this project and Mhairi McFarlane from NCC for advice on the survey design. Information on habitats and land management history was jointly developed and shared by Manitoba Tall Grass Prairie Preserve Management Committee member organizations (Manitoba Sustainable Development, Nature Manitoba, Environment and Climate Change Canada, Manitoba Habitat Heritage Corporation, and NCC). We acknowledge also Brent Sinclair for hosting the work on the collection in his lab at the University of Western Ontario (UWO) as well as Jennifer Ho, undergraduate student at UWO, for help in sorting the collection. Many thanks also to Jeremy de Waard at the Biodiversity Institute of Ontario for including voucher specimens in the Barcode of Life Database (BOLD), Randall D. Mooi and Janis Klapecki at the Manitoba Museum for curating dry voucher specimens, and Valérie Briand at the Université Rennes 1, for literature search and formatting. This manuscript was vastly improved by the editing of Associate Editor Don McAlpine.

\section{Literature Cited}

Austin, J.E., and D.A. Buhl. 2013. Relating Yellow Rail (Coturnicops noveboracensis) occupancy to habitat and landscape features in the context of fire. Waterbirds 36: 199-213. https://doi.org/10.1675/063.036.0209

Baur, B., C. Cremene, G. Groza, A.A. Schileyko, A. Baur, and A. Erhardt. 2007. Intensified grazing affects endemic plant and gastropod diversity in alpine grasslands of the Southern Carpathian mountains (Romania). Biologia 62: 438-445. https://doi.org/ 10.2478/s11756-007-0086-4

Becker, D.A. 1989. Five years of annual prairie burns. Pages 163-168 in Proceedings of the Eleventh North American Prairie Conference. Prairie Pioneers: Ecology, History and Culture. 7-11 August 1988, Lincoln, Nebraska. Edited by T.B. Bragg and J. Stubbendieck. University of Nebraska Printing, Lincoln, Nebraska, USA. Accessed 10 January 2020. http://digital.library.wisc.edu/1711.dl/ EcoNatRes.NAPC11.

Bellido, A. 1987. Field experiment about direct effect of a heathland prescribed fire on microarthropod community. Revue d'Ecologie et de Biologie du Sol 24: 603-633.

Bleho, B.I., N. Koper, C.L. Borkowsky, and C.D. Hamel. 2015. Effects of weather and land management on the Western Prairie Fringed-orchid (Platanthera praeclara) at the northern limit of its range in Manitoba, Canada. American Midland Naturalist 174: 191-203. https://doi. org/10.1674/0003-0031-174.2.191

Boag, D.A., and W.D. Wishart. 1982. Distribution and abundance of terrestrial gastropods on a winter range of bighorn sheep in southwestern Alberta. Canadian Journal of Zoology 60: 2633-2640. https://doi.org/10.1139/z 82-338

Boschi, C., and B. Baur. 2007. The effect of horse, cattle and sheep grazing on the diversity and abundance of land snails in nutrient-poor calcareous grasslands. Basic and Applied Ecology 8: 55-65. https://doi.org/10.1016/j. baae.2006.02.003

Botkin, D.B. 1990. Discordant Harmonies: A New Ecology for the Twentieth Century. Oxford University Press, New York, New York, USA.

Burkman, M.A. 1993. The use of fire to manage breeding habitat for yellow rails. M.Sc. thesis, Northern Michigan University, Marquette, Michigan, USA.

British Columbia Ministry of Forests. 2008. Land snails and slugs as ecological indicators of logging practices: recommendations for adaptive management. Accessed 28 December 2019. http://www.for.gov.bc.ca/hfd/library/ FIA/2008/FSP_Y083030a.pdf.

Brooks, M., and M. Lusk. 2008. Fire Management and Invasive Plants: a Handbook. United States Fish and Wildlife Service, Arlington, Virginia, USA.

Buehler, D.A., A.M. Roth, R. Vallender, T.C. Will, J.L. Confer, R.A. Canterbury, S.B. Swarthout, K.V. Rosenberg, and L.P. Bulluck. 2007. Status and conservation priorities of Golden-winged Warbler (Vermivora chrysoptera) in North America. Auk 124: 14391445. https://doi.org/10.1093/auk/124.4.1439

CESCC (Canadian Endangered Species Conservation Council). 2016. Wild Species 2015: The General Status of Species in Canada. National General Status Working Group. Accessed 10 January 2020. http://www.registr elep-sararegistry.gc.ca/virtual_sara/files/reports/Wild \%20Species\%202015.pdf.

Clarke, A.H. 1981. The Freshwater Molluscs of Canada. National Museum of Natural Sciences. National Museum of Canada, Ottawa, Ontario, Canada.

Cremene, C., G. Groza, L. Rakosy, A.A. Schileyko, A. Baur, A. Erhardt, and B. Baur. 2005. Alterations of steppe-like grasslands in Eastern Europe: a threat to regional biodiversity hotspots. Conservation Biology 19: 1606-1618. https://doi.org/10.1111/j.1523-1739.2005.00 084.x

Damhoureyeh, S.A., and D.C. Hartnett. 1997. Effects of bison and cattle on growth, reproduction, and abundances of five Tall Grass Prairie forbs. American Journal of Botany 84: 1719-1728. https://doi.org/10.2307/2446471

Damhoureyeh, S.A., and D.C. Hartnett. 2002. Variation in grazing tolerance among three tallgrass prairie plant species. American Journal of Botany 89: 1634-1643. https://doi.org/10.3732/ajb.89.10.1634

Davis, M.A., D.W. Peterson, P.B. Reich, M. Crozier, T. Query, E. Mitchell, J. Huntington, and P. Bazakas. 2000. Restoring savanna using fire: impact of the breeding bird community. Restoration Ecology 8: 30-40. https://doi.org/10.1046/j.1526-100x.2000.80005.x

Dvořáková, J., and M. Horsák. 2012. Variation of snail assemblages in hay meadows: disentangling the predictive power of abiotic environment and vegetation. Malacologia 55: 151-162. https://doi.org/10.4002/040. 055.0110

Fischer, S.F., P. Poschlod, and B. Beinlich. 1996. Experimental studies on the dispersal of plants and animals on sheep in calcareous grasslands. Journal of Applied Ecology 33: 1206-1222. https://doi.org/10.23 07/2404699 
Forsyth, R.G. 2004. Land snails of British Columbia. Royal BC Museum Handbook. Royal British Columbia Museum, Victoria, British Columbia, Canada.

Forsyth, R.G. 2005. Terrestrial Gastropods of the Upper Fraser Basin of British Columbia. Living Landscapes, Royal British Columbia Museum, Victoria, British Columbia, Canada. Accessed 28 December 2019. https:// royalbcmuseum.bc.ca/exhibits/living-landscapes/upper fraserbasin/ufb_snails/UFB-Snails.pdf.

Forsyth, R.G., and M.J. Oldham. 2016. Terrestrial molluscs from the Ontario Far North. Check List 12: 1881. https://doi.org/10.15560/12.3.1881

Glaser, A. 2012. America's Grasslands Conference: status, threats, and opportunities. In Proceedings of the 1st Biennial Conference on the Conservation of America's Grasslands. August 15-17, 2011, Sioux Falls, South Dakota. National Wildlife Federation and South Dakota State University, Washington, DC and Brookings, South Dakota, USA.

Gottesfeld, L.M.J. 1994. Aboriginal burning for vegetative management in northwestern British Columbia. Human Ecology 22: 171-188. https://doi.org/10.1007/ BF02169038

Grant, T.A., E.M. Madden, T.L. Shaffer, and J.S. Dockens. 2010. Effects of prescribed fire on vegetation and passerine birds in northern mixed-grass prairie. Journal of Wildlife Management 74: 1841-1851. https://doi.org/ 10.2193/2010-006

Hamel, C.D., R. Reisz, G. Fortney, R. Jones, and D. Pietruszewski. 2006. Conservation Area Plan for the Tallgrass Aspen Parkland. Nature Conservancy of Canada, Manitoba Region, Winnipeg, Manitoba, Canada / The Nature Conservancy, Karlstad Field Office, Karlstad, Minnesota, USA.

Harper, M.G., C.H. Dietrich, R.L. Larimore, and P.A. Tessene. 2000. Effects of prescribed fire on prairie arthropods: an enclosure study. Natural Areas Journal 20: 325-335.

Hettenbergerová, E., M. Horsák, R. Chandran, M. Hájek, D. Zelený, and J. Dvořáková. 2013. Patterns of land snail assemblages along a fine-scale moisture gradient. Malacologia 56: 31-42. https://doi.org/10.4002/ 040.056 .0227

Horsák, M., and M. Chytry. 2014. Unimodal latitudinal pattern of land-snail species richness across northern Eurasian lowlands. PLoS ONE 9: e104035. https://doi. org/10.1371/journal.pone.0104035

Jordan, S.F., and S.H. Black. 2012. Effects of forest land management on terrestrial mollusks: a literature review. USDA Forest Service, Region 6 \& USDI Oregon/ Washington Bureau of Land Management, Portland, Oregon, USA. Accessed 10 January 2020. https://www. fs.fed.us/r6/sfpnw/issssp/documents2/cpt-ig-effects-tomollusks-bibliography-2012-02.docx.

Kaufman, D.W., E.J. Finck, and G.A. Kaufman. 1990. Small mammals and grassland fires. Pages 46-80 in Fire in North American Tall Grass Prairies. Edited by S.L. Collins and L.L. Wallace. University of Oklahoma Press, Norman, Oklahoma, USA.

Kiss, L., and F. Magnin. 2003. The impact of fire on some Mediterranean land snail communities and patterns of post-fire recolonization. Journal of Molluscan Studies 69: 43-53. https://doi.org/10.1093/mollus/69.1.43

Kiss, L., and F. Magnin. 2006. High resilience of Mediterranean land snail communities to wildfires. Biodiversity and Conservation 15: 2925-2944. https://doi. org/10.1007/s10531-005-3430-4

Klaus, N.A., S.A. Rush, T.S. Keyes, J. Petrick, and R.J. Cooper. 2010. Short-term effects of fire on breeding birds in southern Appalachian upland forests. Wilson Journal of Ornithology 122: 518-531. https://doi.org/10. 1676/09-105.1

Knapp, A.K., J.M. Blair, J.M. Briggs, S.L. Collins, D.C. Hartnett, L.C. Johnson, and A.G. Towne. 1999. The keystone role of bison in North American tallgrass prairie: bison increase habitat heterogeneity and alter a broad array of plant, community, and ecosystem processes. BioScience 49: 39-50. https://doi.org/10.1525/ bisi.1999.49.1.39

Knapp, E.E., B.L. Estes, and C.E. Skinner. 2009. Ecological effects of prescribed fire season: a literature review and synthesis for managers. USDA General Technical Report PSW-GTR-224. U.S. Department of Agriculture, Forest Service, Pacific Southwest Research Station, Albany, California, USA. Accessed 10 January 2020. https://www.fs.fed.us/psw/publications/docu ments/psw_gtr224/.

Legendre, P., and L. Legendre. 2007. Numerical Ecology. Elsevier, Amsterdam, The Netherlands.

Lewis, H.T. 1985. Why Indians burned: specific versus general reasons. In Proceedings of Symposium and Wilderness Fire, Missoula, Montana, Nov 15-18, 1983. GTRINT-182. Edited by J.E. Lotan, B.M. Kilgore, W.C. Fischer, and R.W. Mutch. USDA Forest Service, Intermountain Forest and Range Experiment Station, Ogden, Utah, USA.

Ludwick, T.J., and R.K. Murphy. 2006. Fire history, passerine abundance, and habitat on a North Dakota drift plain prairie. Prairie Naturalist 38: 1-11.

Lydeard, C., R.H. Cowie, W.F. Ponder, A.E. Bogan, P. Bouchet, S.A. Clark, K.S. Cummings, T.J. Frest, O. Gargominy, D.G. Herbert, R. Hershler, K.E. Perez, B. Roth, M. Seddon, E.E. Strong, and F.G. Thompson. 2004. The global decline of nonmarine mollusks. Bioscience 54: 321-330. https://doi.org/10.1641/ 0006-3568(2004)054[0321:tgdonm]2.0.co;2

Madden, E.M., A.J. Hansen, and R.K. Murphy. 1999. Influence of prescribed fire history on habitat and abundance of passerine birds in northern mixed-grass prairie. Canadian Field-Naturalist 113: 627-640. Accessed 28 December 2019. https://biodiversitylibrary.org/page/ 34235497.

Minnesota Department of Natural Resources. 2005. Field Guide to the Native Plant Communities of Minnesota: The Prairie Parkland and Tallgrass Aspen Parklands Provinces. Ecological Land Classification Program, Minnesota County Biological Survey, and Natural Heritage and Nongame Research Program, Minnesota Department of Natural Resources, St. Paul, Minnesota, USA.

Nekola, J.C. 2002. Effects of fire management on the richness and abundance of central North American grass- 
land land snail faunas. Animal Biodiversity and Conservation 25: 53-66.

Nekola, J.C. 2005. Geographic variation in richness and shell size of eastern North American land snail communities. Records of the Western Australian Museum, Supplement 68: 39-51. https://doi.org/10.18195/issn.0313122x.68.2005.039-051

Nekola, J.C., and B.F. Coles. 2010. Pupillid land snails of eastern North America. American Malacological Bulletin 28: 1-29. https://doi.org/10.4003/006.028.0221

Ohrtman, M.K., S.A. Clay, D.E. Clay, E.M. Mousel, and A.J. Smart. 2011. Preventing saltcedar (Tamarix spp.) seedling establishment in the Northern Prairie Pothole Region. Invasive Plant Science and Management 4: 427-436. https://doi.org/10.1614/ipsm-d-11-00012.1

Pyne, S.J. 1983. Indian fires: the fire practices of North American Indians transformed large areas from forest to grassland. Natural History 92: 6-11.

R Core Team. 2008. R: a language and environment for statistical computing. R Foundation for Statistical Computing, Vienna.

Ramette, A. 2007. Multivariate analyses in microbial ecology. FEMS Microbiology Ecology 62: 142-160. https:// doi.org/10.1111/j.1574-6941.2007.00375.x

Ray, E.J., and E.A. Bergey. 2015. After the burn: factors affecting land snail survival in post-prescribed-burn woodlands. Journal of Molluscan Studies 81: 44-50. https://doi.org/10.1093/mollus/eyu051

Reinking, D.L. 2005. Fire regimes and avian responses in the central tallgrass prairie. Studies in Avian Biology 30: 116-126.

Rook, A.J., B. Dumont, J. Isselstein, K. Osoro, M.F. WallisDeVries, G. Parente, and J. Mills. 2004. Matching type of livestock to desired biodiversity outcomes in pastures - a review. Biological Conservation 119: 137-150. https://doi.org/10.1016/j.bio con.2003.11.010

Saestedt, T.R., and R.A. Ramundo. 1990. The influence of fire on belowground processes of tallgrass prairie. Pages 99-117 in Fire in North American Tall Grass Prairies. Edited by S.L. Collins and L.L. Wallace. University of
Oklahoma Press, Norman, Oklahoma, USA.

Sampson, F., and F. Knopf. 1994. Prairie conservation in North America. Bioscience 44: 418-421.

Santos, X., V. Bros, and E. Ros. 2012. Contrasting responses of two xerophilous land snails to fire and natural reforestation. Contributions to Zoology 81: 167-180. https://doi.org/10.1163/18759866-08103004

Shimodaira, H. 2004. Approximately unbiased tests of regions using multistep-multiscale bootstrap resampling. Annals of Statistics 32: 2616-2641. https://doi.org/10. 1214/009053604000000823

Sveinson Pelc, J. 2013. Characterization of a wild fire event in the tall grass prairie region of Manitoba. Pages 3233 in Proceedings of the Manitoba Tall Grass Prairie Preserve Research Symposium 2014. Edited by M. Pearn and C.D. Hamel. Nature Conservancy of Canada, Winnipeg, Manitoba, Canada.

Swengel, A.B. 1996. Effects of fire and hay management on the abundance of prairie butterflies. Biological Conservation 76: 73-85. https://doi.org/10.1016/0006-3207 (95)00085-2

Towne, G., and C. Owensby. 1984. Long-term effects of annual burning at different dates in ungrazed Kansas tallgrass prairie. Journal of Range Management 37: 392-397. https://doi.org/10.2307/3899622

van Klink, R., F. van der Plas, C.G.E. van Noordwijk, M.F. Wallis DeVries, and H. Olff. 2015. Effects of large herbivores on grassland arthropod diversity. Biological Review 90: 347-366. https://doi.org/10.1111/brv.12113

Vierling, K., and L. Lentile. 2006. Red-headed woodpecker nest-site selection and reproduction in mixed ponderosa pine and aspen woodland following fire. Condor 108: 957-962. https://doi.org/10.1093/condor/ 108.4.957

Williams, G.W. 2000. Reintroducing Indian-type fire: implications for land managers. Fire Management Today 60: $40-48$.

Received 25 January 2019

Accepted 19 December 2019 